\title{
O GOMBROWICZOWSKIM KICZU W KONTEKŚCIE TEORII (PO)NOWOCZESNOŚCI
}

DAGMARA JASZEWSKA

\author{
Wydział Teologiczny Uniwersytetu Kardynała Stefana \\ Wyszyńskiego w Warszawie \\ Department of Theology Cardinal Stefan Wyszyński University \\ in Warsaw (Poland) \\ djaszewska@wp.pl
}

Kicz istnieje chyba od zawsze - przynajmniej odkąd istnieją klasy wyższe i niższe, arystokracja i pospólstwo, i odkąd ci pierwsi próbują odciąć się od drugich, podczas gdy drudzy aspirują, naśladują, pretendują... Ale kicz jest też w jakimś sensie dzieckiem nowoczesności. W XX wieku zrodziły się idealne dlań warunki: z jednej strony łatwa przemysłowa produkcja, oferująca tony plastikowych bubli; z drugiej - postępująca demokratyzacja życia, a wraz z nią pokusy uwzględniania przy tworzeniu i odbiorze sztuki zasady „wspólnego mianownika”. Od początku XX wieku nasilała się krytyka kiczu, która właśnie w kulturze masowej upatrywała rozkwit tandety i powierzchownej estetyzacji ${ }^{1}$. Przede wszystkim jednak panujący co najmniej do połowy XX wieku modernizm - z jego obsesją „sztuki wysokiej” i „wysokiego artysty”, która niosła ze sobą przymus nowatorstwa i oryginalności - pozwalał takim filozofom jak Hermann Broch czy Theodor Adorno na odcinanie się od kiczu jako stereotypu, banału, karykatury sztuki, sztuki złej czy też fałszywej².

${ }^{1}$ Np. J. Ortega y Gasset, Bunt mas, tłum. P, Niklewicz, Warszawa 2006; D. McDonald, Teoria kultury masowej, [w:] Kultura masowa, tłum. i oprac. Cz. Miłosz, Kraków 2002.

2 W przypadku Adorna była to awangarda, z odkrytą na nowo kategorią wzniosłości; zob. T. Adorno, Teoria estetyczna, tłum. K. Krzemień-Ojak, Warszawa 1994. Z kolei koncepcja Brocha była bardziej uniwersalistyczna - zakładała powiązanie estetyki i etyki i widziała rolę sztuki w szukaniu autentyczności artystycznego wyrazu, utożsamiając ją z poszukiwaniem prawdy; zob. H. Broch, Kilka uwag 
Współcześnie, w czasach późnonowoczesnych (czy, jak kto woli, ponowoczesnych), kiczu piętnować już nie wypada: umieszczamy raczej krytykę kiczu w - dawno już zburzonych - murach hardej i dumnej nowoczesności ${ }^{3}$. Przyczyniła się do tego sama nowoczesna sztuka: dokonania późnej awangardy (zwłaszcza pop-artu, który postawił znak równości pomiędzy sztuką a banałem kultury masowej) sprowokowały wręcz dyskusje o końcu sztuki i końcu estetyki ${ }^{4}$. Z drugiej strony, kicz jest dziś usprawiedliwiony właśnie dlatego, że nowoczesność wcale się nie skończyła, ale przeciwnie - jej symptomy (homogenizacja, demokratyzacja kultury) nasiliły się w olbrzymim stopniu, powodując dalsze zacieranie granic między „sztuką wysoką” a „sztuką niską". To wszystko przyczyniło się do postmodernistycznego poglądu o kryzysie, dewaluacji kultury wysokiej, o braku kryteriów „prawdziwej sztuki" w czasach powszechnej estetyzacji ${ }^{5}$.

Sądzę, że nie da się dziś mówić o kiczu, nie odnosząc się przy tym do filozoficznego i kulturoznawczego namysłu nad nowoczesnością. Co więcej, analizując temat kiczu w twórczości Witolda Gombrowicza, warto również umiejscowić to zagadnienie w kontekście stosunku pisarza do nowoczesności ${ }^{6}$. Na szczęście jest to zadanie o tyle wdzięczne, że mowa o artyście filozofującym, takim, którego z powodzeniem można określić mianem filozofa nowoczesności ${ }^{7}$. Podejmując w niniejszym artykule zagadnienie

o kiczu, [w:] idem, Kilka uwag o kiczu i inne eseje, tłum. J. Garewicz, D. Borkowska, R. Turczyn, Warszawa 1998.

3 Świetnie rekonstruuje modernistyczną koncepcję sztuki z jej elitaryzmem (po to zresztą, by poddać ją krytyce z punktu widzenia neopragmatyzmu) Richard Shusterman; zob. idem, Estetyka pragmatyczna. Żywe piękno i refleksja nad sztuka, tłum. A. Chmielewski, Wrocław 1998, zwłaszcza rozdział „Piękna sztuka rapowania".

4 Zob. np. K. Piątkowski, Kicz jako problem antropologiczny, [w:] Kiczosfery współczesności, red. W.J. Burszta, E. Sekuła, Warszawa 2008, s. 12-13.

5 Zob. np. G. Dziamski, Co oznacza formuła „kryzys estetyki”?, „Kultura Współczesna" 1995, nr 3-4, s. 56-65.

${ }^{6}$ Do zagadnień modernizmu i postmodernizmu odwołał się już Jerzy Jarzębski, poruszając temat kiczu w twórczości Gombrowicza; zob. J. Jarzębski, Kicz jest w nas: Gombrowicza romans z kiczem, „Teksty Drugie” 1996, nr 4 (40), s. 56.

7 Zob. tom: Gombrowicz filozof, wybór i oprac. F. Cataluccio, J. Illg, tłum. K. Bielas, F.M. Cataluccio, Kraków 1991. Gombrowicza koncepcja sztuki (i życia) 
kiczu u Gombrowicza, jednocześnie pozostaję w kręgu jego koncepcji nowoczesności i próbuję odtworzyć pewne jej rysy.

\section{GOMBROWICZA WALKA Z KICZEM: MIĘDZY MODERNIZMEM A POSTMODERNIZMEM}

Jerzy Jarzębski trafnie zauważył, że Gombrowicz stoi niejako pomiędzy epokami i można przypisać mu cechy zarówno modernisty, jak i postmodernisty: „jeszcze »awangardowy«, jeszcze wierzący w wyraźny »postęp « na terenie sztuki, literatury czy muzyki, ale już skłonny do parodii, dystansu, igrania $\mathrm{z}$ formą, już drwiący także z ortodoksów awangardowej doktryny"8. Krytyk ten dodaje, iż można odczytać dzieło autora Ferdydurke na sposób bardziej modernistyczny albo też postmodernistyczny, akcentując, z jednej strony, odkrycia czy nowe idee twórcze, a z drugiej - zróżnicowanie, niekonsekwencję głoszonych poglądów, pociąg do niższości, zabawy formą, jak i tendencję do jej burzenia. W pierwszym przypadku będzie Gombrowicz raczej krytykował (parodiował) kicz, w drugim - będzie bawił się nim, a nawet go "produkował".

Jeśli był Gombrowicz modernistą - to już niewierzącym ${ }^{10}$. Jest wprawdzie u autora Ferdydurke modernistyczna tęsknota za Wielką Sztuką, jednakże Gombrowiczowska walka o wielkość przypomina raczej ideę „tęgiego poety” Rorty'ego - filozofa uznawanego wszak za myśliciela ponowoczesnego ${ }^{11}-$

okazała się - w miarę upływu lat - tak przenikliwa, głęboka i dalekowzroczna, że porównywano ją później z powodzeniem do różnych idei, które kolejno opisywały sytuację kulturową powojennej Europy. Znajdowano w Gombrowiczu więc proroka strukturalizmu, egzystencjalizmu czy też podstmodernizmu; z perspektywy czasu można nawet powiedzieć: namysłu nad nowoczesnością i tak zwaną późną nowoczesnością (ponowoczesnością).

8 J. Jarzębski, op. cit., s. 69.

9 Ibidem.

10 Myślę, że można by nawet dyskutować z tezą Jarzębskiego, iż pisarz „wciąż wierzył w postęp" nawet w dziedzinie sztuki, przypominając słowa samego pisarza: „Ja, niewierzący?” (W. Gombrowicz, Dziennik 1966-1969, Kraków 1992, s. 46-47). Świadczy o tym krytycyzm pisarza wobec dokonań współczesnej mu awangardy (zresztą Jerzy Jarzębski odnajduje w Ferdydurke „drwinę z awangardowej poezji”; J. Jarzębski, op. cit., s. 59.)

11 A. Szahaj, Ironia i miłość. Neopragmatyzm Richarda Rorty'ego w kontekście sporu o postmodernizm, Wrocław 2002, s. 188-208, zwłaszcza podrozdział: „Czy 
postaci starającej się (tak jak „liberalna ironistka”) poradzić sobie w erze przygodności. Według Rorty’ego, wielkość i oryginalność, nieuleganie „innym słownikom", to w dzisiejszych czasach zadanie tragicznie trudne ${ }^{12}$.

Jeśli zaś był Gombrowicz postmodernistą, to też „niewierzącym” - nie takim, który by cieszył się z wielości, bezładu i pomieszania. Cierpiał raczej z powodu niemożności wypowiedzenia się ,jak należy”. Dlatego tytułowe "między modernizmem a postmodernizmem" nie oznacza zmiennych proporcji tych idei w myśli pisarza, ale raczej to, iż umknął i tym razem przed ideologiami, choć były mu bliskie rządzące nimi niepokoje.

W każdym razie, choć „Wielka Forma” pozostała nadal postulatem i marzeniem, Gombrowicz przynajmniej wiedział, co nią nie jest, i nieustannie to odrzucał, degradował. Można te ataki na formę opisać jako ataki na kicz właśnie. Jarzębski w swoim doskonałym studium omówił wiele przykładów Gombrowiczowskiego „kiczu przedstawionego"13. Pisarz bezwzględnie wyśmiewał zastane przezeń formy społeczne, pokazując trudną do zniesienia stereotypowość, sztampowość, śmieszność i sztuczność swoich bohaterów. Nieudane formy ludzkie okazywały się po prostu nieestetyczne: albo niewystarczające, zbyt płaskie, powierzchowne, brzydkie (jak forma salonowa arystokratów z opowiadania Biesiada u hrabiny Kotłubaj); albo odwrotnie - zbyt przylizane i uładzone, zbyt „śliczne” (Zosia z Ferdydurke), zbyt niedojrzałe i infantylne (Zuta $z$ tejże powieści), ale przede wszystkim zbyt dojrzałe, pretendujące do wielkości (mecenas Kraykowski). Gombrowicz krytykował więc codzienny kicz obyczajowy jako „złą sztukę” - tak jak rasowy modernista. Mógłby w tym momencie podać sobie ręce z Adornem i Brochem - krytyka kiczowatych form jest gestem modernistycznego Rozumu, stawiającego sztuce wysokie wymagania oryginalności, autentyczności, wzniosłości i bezinteresowności.

Ale - w przeciwieństwie do wspomnianych wyżej filozofów Gombrowicz nie ma już w ręku talii asów, nie umie wskazać na to, co jest doskonałe i dlatego nie jest kiczem. Tu kończy się więc „modernizm” pisarza,

Rorty jest filozofem postmodernistycznym?".

${ }_{12}$ Zob. R. Rorty, Przygodność, ironia i solidarność, tłum. W.J. Popowski, Warszawa 1996; zob. też: M. Kwiek, Richarda Rorty'ego postmodernistyczny świat ironii, „Kultura Współczesna” 1993, nr 1, s. 57.

13 J. Jarzębski, op. cit., s. 57. 
a zaczyna - kondycja ponowoczesna. Jego alter ego, Józio z Ferdydurke, pragnie stworzyć dojrzałe i wybitne (nie-kiczowate) dzieło, ale nie jest w stanie tego zrobić. Dlaczego tak trudne jest dziś bycie poważnym, napisanie kolejnego „dzieła kultury wysokiej”? Jak autobiograficznie wspomina sam Gombrowicz w Ferdydurke: „Dlaczego jednak pióro mnie zdradziło? Czemu święty wstyd mi nie dozwolił napisać notorycznie zdawkowej powieści i zamiast snuć górne wątki z serca, z duszy, wysnułem je z dolnych odnóży?"14.

Dlaczego zatem Gombrowicz nie chce napisać „jeszcze jednej książki o miłości”'15? Zauważmy, że skłonność do kiczu przestaje być przypadłością pojedynczego artysty - staje się przekleństwem epoki, w której „wszystko już było”. To tak, jak w znanym passusie z Dopisków na marginesie „Imienia Róży” Umberto Eco - nie można dziś tak po prostu napisać: „kocham cię rozpaczliwie"16. W takiej epoce wiara staje się naiwnością, a prawda - kiczem, bowiem to, co wysokie, również zdaje się popadać w kicz (jak wzniosła mina Miętusa w słynnym pojedynku na miny). Wieczne Dzieła, umieszczone na pokaz w muzeach i szkołach, umarły. Są już zupełnie niezjadliwe, nikt już ich nie doświadcza („Nikt nie może przeczytać więcej niż dwie lub trzy strofy. O Boże! Nie mogę...”17), służą ewentualnie podniesieniu na duchu narodu a przecież takie instrumentalne wykorzystywanie przeczy modernistycznej idei estetycznej kontemplacji.

Notabene, wszelkie demaskatorskie i burzycielskie zapędy Gombrowicza prędzej należałoby określić mianem „świętego gniewu” (pasowałaby tu nawet figura Jezusa wyrzucającego przekupniów ze świątyni!), niż uznać je za

14 W. Gombrowicz, Ferdydurke, Kraków 1987, s. 8.

15 Tamże, s. 13.

16 „O postawie postmodernistycznej myślę jak o postawie człowieka, który kocha jakąś nader wykształconą kobietę i wie, że nie może powiedzieć jej »kocham cię rozpaczliwie«, ponieważ wie, że ona wie (i że ona wie, że on wie), iż te słowa napisała już Liala. Jest jednak rozwiązanie. Może powiedzieć: »Jak powiedziałaby Liala, kocham cię rozpaczliwie«. W tym miejscu, uniknąwszy fałszywej niewinności, oznajmiwszy jasno, że nie można już mówić w sposób niewinny, powiedziałby jednak ukochanej to, co chciał jej powiedzieć: że ją kocha, ale że ją kocha w epoce utraconej niewinności”. U. Eco, Dopiski na marginesie „Imienia róży”, [w:] idem, Imię róży, tłum. A. Szymanowski, Warszawa 1987, s. 618.

17 W. Gombrowicz, Ferdydurke, op. cit., s. 44. 
przykład „zamachu na świętości” (a ich autora wykreślić z listy lektur...). Pokazując kiczowatość religii, patriotyzmu, wszelkich wartości, wcale nie odrzuca Gombrowicz Prawdy czy Piękna, ale ich karykatury, łatwość ich substytutów w epoce "gotowców”. Idąc tym tropem, współcześni młodzi konserwatyści związani z Kościołem doszukują się nawet pokrewieństwa myśli Gombrowicza i prymasa Wyszyńskiego ${ }^{18}$, co jest dość karkołomne, ale prawdziwe o tyle, że Gombrowicz tak samo tęsknił do Prawdy i Piękna, jak katolicy i inni wierzący; nie zadowalał się jedynie skarlałą formą tych wartości ${ }^{19}$.

Gombrowicz był więc (niewierzącym wprawdzie) modernistą - w takim stopniu, w jakim wciąż tęsknił za "Wielką Formą" i krytykował formy niedojrzałe. Bywał też postmodernistą, jeśli ostatecznie to, co wychodziło mu spod pióra (a sam twierdził, że nigdy nie wie, co mu ostatecznie wyjdzie ${ }^{20}$ ), okazywało się wciąż parodią, pastiszem, a więc de facto "grą resztkami”. Jego walka z kiczem była więc również postmodernistyczna. Ale nie była to strategia, którą by - jak wojujący postmoderniści - proklamował czy zalecał. Bliższa byłaby mu raczej wiara w sztukę jako „niedokończony projekt”.

Co więc w zamian - skoro $\mathrm{w}$ miejsce zburzonych form nie proponował Gombrowicz form nowych? Otóż - Niedojrzałość. Trafnie zauważył Jarzębski, że choć możliwe jest uproszczone utożsamienie kiczu z Niedojrzałością, to bliżej mu zdecydowanie do formy, do dojrzałości ${ }^{21}$. Kicz

18 Poświęcony został temu zagadnieniu cały 34 numer magazynu „Pressje” z 2013 roku (temat numeru: „Forma polska”). Redaktorzy tomu krytykują uproszczone i mocno utrwalone nawet w III RP przeciwstawianie tradycyjnej, siermiężnej „formy polskiej”, uosabianej przez kardynała Wyszyńskiego, wolności i nowoczesności Gombrowicza, dowodząc, wbrew powszechnym odczytaniom, że tych dwóch Polaków łączyło wiele wspólnych ideałów. Zobacz w tym numerze m.in. teksty: P. Rojek, Gombrowicz i Wyszyński; J. Lubelski, Gombrowicz, zrozpaczony konserwatysta.

19 Pojawiają się już odczytania filozofii Gombrowicza w kategoriach poszukiwania sacrum; zob. np. J. Lubelski, Ssanie. Głód sacrum w literaturze polskiej, Warszawa 2015.

20 Zob. np. Gombrowicz filozof, op. cit., s. 27.

${ }^{21}$ Jarzębski trafnie sytuuje zjawisko kiczu miedzy kluczowymi dla Gombrowicza dychotomiami: „formy i chaosu, Dojrzałości i Niedojrzałości, Wyższości i Niższości, Starości i Młodości”. Przede wszystkim zwraca jednak uwagę, że kicz wymyka się prostym kategoryzacjom. Z pewnością - zauważa - nie da się u Gombrowicza 
może być sztuką niedojrzałą (niedopracowaną, infantylną, uproszczoną), ale zarazem Gombrowiczowska Niedojrzałość nie jest kiczowa: jest śmiertelnie poważna. Gombrowicz odwraca logikę, pokazując, że Niedojrzałość jest dojrzała (bo szczera, autorefleksyjna), natomiast Dojrzałość to kicz, fałsz. To niedojrzałość (po) dojrzałości; odpowiada ona postmodernistycznej wersji „wiem, że nic nie wiem” czy „vanitas vanitatum”; jest czystą potencją, a nawet aktem pokory - bo jest milczeniem. Trudna, jeśli nie niemożliwa (ciągłe popadanie w formy), jest spełnieniem przepowiedni Ernesta Gellnera: skoro wszystko już było, postmoderniści powinni milczeć 22 .

\section{GOMBROWICZA „ROMANS Z KICZEM” (W STRONĘ PONOWOCZESNOŚCI)}

Nawiązując do tytułu przywoływanego w eseju Jarzębskiego, chciałabym teraz przyjrzeć się drugiemu członowi Gombrowiczowskiego ambiwalentnego stosunku do kiczu (choć oczywiście oba te aspekty - krytyka i używanie kiczu jedynie z trudem i ze stratą dla ujęcia całości dają się analizować oddzielnie).

Dlaczego Gombrowicz sięga po kicz, dlaczego nawet - jak pisze Jarzębski na sposób postmodernistyczny jest bardziej jego producentem niż krytykiem? ${ }^{23} \mathrm{Z}$ pewnością fundamentalna jest tu Gombrowiczowska obsesja Niższości. Można ją pewnie tłumaczyć za pomocą psychoanalizy, uznać za oryginalną idiosynkrazję - ale ma też ona uzasadnienie w nadchodzącej kulturze późnej nowoczesności. Oznacza ona u Gombrowicza wiele rzeczy.

postawić kiczu po jednej stronie barykady, a po drugiej sztuki „wysokiej” czy „dojrzałej”. Wynika to z niejednoznaczności pojęć, jakimi posługiwał się Gombrowicz. Jak pisze: „Jeżeli miałby być kicz sztuką niedojrzałą, niedomyślaną i niedopracowaną, to - rzecz jasna - znajdowałby się gdzieś blisko Młodości i Niedojrzałości; zdecydowanie po jednej stronie rzeczonej osi przebiegającej przez świat. Gdyby był naiwną "sztuką szczęścia", przytwierdzającą naszym prymitywnym gustom i wstydliwym marzeniom - także mieściłby się bez reszty po tej samej stronie. Jeśli jednak uznamy go za sztukę po prostu małowartościową, bo opartą na stereotypach i kliszach, okaże się, że łatwiej znaleźć mu miejsce po stronie Dojrzałości i Formy”. J. Jarzębski, op. cit., s. 55-56.

22 E. Gellner, Postmodernizm, rozum i religia, tłum. M. Kowalczuk, Warszawa 1997, s. 53.

${ }^{23}$ J. Jarzębski, op. cit., s. 69. 
Po pierwsze, miłość do prawdziwej „niższej sfery”. Tu pisarz przewidział zadziwiającą demokratyzację kultury naszych czasów. Józio z Ferdydurke wręcz perwersyjnie zakochany jest w parobkach, pensjonarkach, wieśniaczkach - kocha niższość zieloność, mętność. Treści „niskie” mają nawet nad wysokimi pewną przewagę - nie ma w nich pretensji, udawania, męczącego aspirowania. Pociąg do niższości jest jakże kiczowatym gestem zmęczonego swą wyższością inteligenta, uwiedzionego przez demokratyczną epokę. Pojawił się on już w młodopolskiej chłopomanii i został nieśmiało, z jąkaniem wyrażony w Ferdydurke w pragnieniu, by „zbra...tać” się z parobkiem.

Po drugie, za Niższością kryje się młodość. Nie na darmo uznano Gombrowicza za proroka rewolty młodzieżowej lat 60 . Starszy, chylący czoła przed Młodszym, u Gombrowicza pozostaje jeszcze w ukryciu, pisząc potajemnie w Ferdydurke listy do Nowoczesnej Pensjonarki. Kiedyś więc pociąg ku młodości należał do sfery wstydliwej, ta fascynacja nie przeszkadzała jednak w realizowaniu na co dzień Wyższości - w byciu Dojrzałym. Dziś często jawnie widzimy mędrców „bezradnych” wobec młodzieńczej urody i świeżości (vide plaga reżyserów, którzy dali się uwieść młodości, jak Krzysztof Zanussi, zatrudniający w filmie Dodę, czy nawet Woody Allen, zachwycający się dość prymitywną urodą Scarlett Johansson - niestety, w ich przypadku, inaczej niż u Gombrowicza, to raczej kicz nieświadomy....). W epoce późnej nowoczesności pozycji nie zdobywają już mędrcy stateczni, dojrzali, elitarni; mamy do czynienia z przemocą kultury masowej, obecnej już za czasów Witkacego, narzekającego na wszechobecne i gwałcące uszy radio ${ }^{24}$.

Po trzecie, Niższość to wstydliwe zakamarki duszy (i ciała). Gombrowicz, nieustannie przypominając o rozdwojeniu, o ciemnej stronie duszy, o „podoficjalności" (ale nie jako czymś, co należy przezwyciężyć, zdusić w sobie, ale tym, co ma prawo istnieć, podobnie jak dziecko czy młodzieniec w człowieku dorosłym), tworzy płaszczyznę, na której możliwa jest rehabilitacja kiczu. To też jeden z aspektów Niedojrzałości u Gombrowicza - sfera instynktu, popędu u człowieka, nagiej cielesności, tego, co „wyssane z dolnych odnóży”. Tu jest Gombrowicz rewolucyjny. Jak wskazuje Jarzębski, od takich wątków zaczął pisarz swoją karierę - jednak pierwsze dzieła zniszczył pod wpływem przerażenia, jakie wywołały one u ich czytelników ${ }^{25}$. Ostatecznie więc

24 S.I. Witkiewicz, Niemyte dusze, Warszawa 1993, s. 334 i n.

25 J. Jarzębski, op. cit., s. 62. 
Gombrowicz nie odważył się całkowicie oddać swym wstydliwym namiętnościom i poprzestał na „romansowaniu z kiczem”. Jarzębski omawia w tym kontekście powieść Opętani, pomyślaną jako zamierzony utwór kultury masowej ${ }^{26}$, a także wcześniejszą próbę napisania celowo „złej powieści”27. Są to strategie - powiedzielibyśmy dziś - postmodernistyczne: podwójna warstwa powieści Gombrowicza nasuwa skojarzenie z prozą Umberto Eco, staje się grą z niższością, a zarazem żywym dowodem postmodernistycznego zacierania się granic między sztuką wysoką a niską. Inną strategią „romansu z kiczem" są na przykład wymieniane przez Jarzębskiego: pastisz, mieszanie gatunków, cytaty, motywy zaczerpnięte z literatury drugorzędnej połączone z nawiązaniami do sztuki wysokiej ${ }^{28}$. Gombrowicz, niczym rasowy postmodernista, miesza i zaciera granice, bawi się kiczem.

Po czwarte - dziecko. Czasem pisarz dosłownie upomina się o dziecko, pytając, jak dorosłe role mają się do „dziecka w sobie” i czy przypadkiem nie doszło tu do jakiejś represji ${ }^{29}$. Wiele dekad przed nastaniem child studies Gombrowiczowi bliski jest postmodernistyczny ogólny klimat „niepowagi”, przyznania się do bycia dzieckiem, infantylizmu, żądania prawa do zabawy (widocznego choćby w powszechnej słabości współczesnych ludzi do gadżetów kultury masowej ${ }^{30}$ ).

Dzięki obsesji Niższości ostatecznie powstaje krajobraz zdecydowanie postmodernistyczny: nic nie jest już jasne ani oddzielone - wysokość i niskość, sztuka i kicz; nie powrócą już modernistyczne estetyki. Podziały

26 Ibidem.

27 Ibidem, s. 54.

28 Ibidem, s. 62.

29 „Nie - o własnym życiu ani słowa - tylko o życiu pszczelarzy. Zapewne, wypisawszy dwadzieścia książek o życiu pszczelarzy, można zrobić się posągiem - ale jakiż związek, gdzie łączność pszczelarskiego króla z jego prywatnym mężczyzną, gdzie łączność mężczyzny z młodzieńcem, młodzieńca z chłopcem, chłopca z dzieckiem, którym przecież onegdaj się było, jaką pociechę ma smarkacz wasz z waszego króla? Życie, które nie przestrzega tych połączeń i nie realizuje własnego rozwoju w całej rozciągłości, jest jak dom budowany od góry i nieuchronnie musi skończyć się na schizofrenicznym rozdwojeniu jaźni”. W. Gombrowicz, Ferdydurke, op. cit., s. 9.

30 E.A. Sekuła, B. Kangur, Kicz jako źródełko radości, [w:] Kiczosfery współczesności, op. cit., s. 43. 
te są dziś nieaktualne także dzięki Gombrowiczowi, który „już na starcie namaszczony był niższą sferą" ${ }^{31}$, wrażliwy na czar kultury masowej, na pokusy demokratyzacji kultury.

Ale z drugiej strony Gombrowicz nie tyle „bawi się kiczem”, co raczej traktuje go śmiertelnie poważnie. Jak pisze Jarzębski, kicz nie jest jedynie żartobliwą „przyprawą” jego twórczości, ale „stałym elementem jego filozofii artystycznych działań”32. Artysta wyznaje swój pociąg do niższości w ramach próby „uczynienia z tej konfesji fundamentu i dowodu autentyczności własnej sztuki”33. Nie tyle więc krotochwilnie oddaje się uciesze kiczu, owej „sztuki szczęścia” ${ }^{4}$; czyni to raczej w geście rozpaczliwej uczciwości. Absolutna szczerość, rachunek sumienia i... kicz - wszystko to wyłazi na wierzch, bo jest „częścią nas”35.

I tu pojawia się drugi, obok pociągu do Niższości, powód skłonności Gombrowicza do kiczu - zazdrość. Bo kiedy Gombrowicz przyznaje się do kochania Niższości, kiedy zanurza się na chwilę w jej odmętach, wówczas zapomina o Wyższości, do której też przecież pretenduje. Jednakże kiedy o niej pamięta, kiedy zdobywa się na gest wykpienia Formy, przejrzenia, ośmieszenia, „skażenia” i odrzucenia taniego kiczu, nieodłącznie towarzyszy mu niechciany kompan - zazdrość, a nawet zawiść. Oczywiście i one zostają usprawiedliwione, ponieważ Gombrowicz znów szczerze wyznaje swoje grzechy i tym samym je unieszkodliwia ${ }^{36}$.

Zazdrość spowodowana jest tym, że jedyna alternatywa dla odrzuconych Form - popadnięcie w Niedojrzałość - oznacza przecież sytuację niekomfortową. Przyznanie się do niej równa się społecznej degradacji, nawet jeśli jest to filozoficzna „niedojrzałość po dojrzałości”. Niedojrzałość w społeczeństwie jest źle widziana (nikt jej nie odróżni od zwykłej niedojrzałości,

31 W. Gombrowicz, Ferdydurke, op. cit., s. 12.

32 J. Jarzębski, op. cit., s. 53-54.

33 Tamże.

${ }^{34}$ A. Moles, Kicz, czyli sztuka szczęścia. Studium o psychologii kiczu, tłum. A. Szczepańska, E. Wende, Warszawa 1978.

35 Jerzy Jarzębski wiele miejsca w swoim eseju poświęca swoistej antropologii Gombrowicza, z której wynika, że kicz bliski jest naturze człowieka, dlatego tak trudno od niego uciec.

36 J. Jarzębski, op. cit., s. 65-66. 
niedorozwinięcia). Dlatego też główny bohater Ferdydurke zazdrości innym... kiczu. Zazdrości odwagi tym, którzy jednak zdecydowali się COŚ powiedzieć, zamiast milczeć (zwłaszcza jeśli wyszło im to całkiem zgrabnie). Józio męczy się swoją „ponowoczesną kondycją” i przyznaje, że dość ma trwania w sytuacji zawieszenia, niepewności, nieautentyczności. Uznanie własnej niedojrzałości jest de facto aktem pokory, na którą tak naprawdę nigdy w życiu Gombrowicz nie chciał się zgodzić, mając nadzieję (całkiem słusznie), że w końcu dopracuje się własnego wielkiego Stylu i Formy.

Czasem Gombrowiczowska zazdrość jest ujęta w cudzysłów, bo tak naprawdę nie ma czego zazdrościć - pisarz chce się tylko poskarżyć, że kondycja niedojrzałości jest trudna. Dzieje się tak wtedy, gdy Gombrowiczowski bohater zazdrości do pewnego stopnia wszystkim dojrzałym, nawet prymitywnym kulturalnym ciotkom. Atak na sądy kulturalnych ciotek ${ }^{37}$ to nie tylko satyra na pozerów, cwaniaków podpinających się pod to, co do nich nie należy, nieautentycznych do bólu, powierzchownych, którzy z dorobku ludzkości czerpią jedynie wyświechtane frazesy i robią za ich pomocą wrażenie (niczym nowojorscy snobi z komedii Woody'ego Allena). To też zawiść wobec tych, którzy radzą sobie w całym tym gąszczu, opanowali sztukę serfowania czy też łatania dziur (albo transwersalności - jak pochlebnie powie o takiej umiejętności Wolfgang Welsch ${ }^{38}$ ), których nie przeraża wielość ani przypadkowość własnych sądów i wyborów.

Już w tym momencie - wykorzystywania, wydawałoby się, prostej satyry - zaczyna się Gombrowicza „romans z kiczem”. Pisarz piętnuje go bowiem nie z poczuciem wyższości, jak moderniści, ale nawet gdy demaskuje

37 „Gdyż kulturę świata obsiadło stado babin przyczepionych, przyłatanych do literatury, niezmiernie wprowadzonych w wartości duchowe i zorientowanych estetycznie, najczęściej z jakimiś swoimi poglądami i przemyśleniami, uświadomionych, że Oskar Wilde się przeżył i że Bernard Shaw jest mistrzem paradoksu. Ach, wiedzą już, że trzeba być niezależną, stanowczą i głębszą, przeto zazwyczaj są niezależne, głębsze i stanowcze”. W. Gombrowicz, Ferdydurke, op. cit., s. 9.

38 W. Welsch, Stajac się soba, tłum. J. Wietecki, [w:] Problemy ponowoczesnej pluralizacji kultury: wokół koncepcji Wolfganga Welscha, red. A. Zeidler-Janiszewska, Poznań 1998, s. 31 i n. 
kicz - jak zauważył Jarzębski - robi to w kiczowy sposób ${ }^{39}$. Gombrowicz parodiuje niejako „od wewnątrz”, mocno „umoczony” we współczesnej mu masowej kulturze i uwiedziony przez jej czar. Dlatego piętnując kicz, sam w niego popada; nie stać go już na dystans - stąd rozpaczliwe strategie „bełtania kompotu” i podglądania Nowoczesnej Pensjonarki. Zdaniem Jarzębskiego, kicz w Ferdydurke został wyśmiany, ale wcale nie rozbrojony ${ }^{40}$. Gombrowicz jedynie neutralizuje go, przyznając się do swej słabości.

Jednakże czasem Józio „zazdrości” już nie tylko z przymrużeniem oka chwilami on zazdrości naprawdę, bo jakąż pokusą wobec świadomego bezformia jest foremność kiczu, a nawet jego ładność, scalenie... Gombrowicz wrażliwy jest na piękno kiczu, bo młodość i kicz oznacza często atrakcyjność i piękno.

\section{GOMBROWICZ JAKO PROROK ESTETYZACJI KULTURY ${ }^{41}$}

Prawda nie jest sprawa argumentów, tylkojest sprawa atrakcji, czyli przyciagania .

Witold Gombrowicz, Dziennik 1953-1956

W przywołanych na początku tekstu koncepcjach modernistów największym wrogiem sztuki i zarazem synonimem kiczu jest estetyzacja. Zwłaszcza dla Hermanna Brocha, który zakładał powiązanie estetyki i etyki, estetyzacja - rozumiana jako nakaz „pracuj pięknie” zamiast „pracuj dobrze” - jest oszustwem, pogonią za efektem (efekciarstwem) zamiast poszukiwania prawdy (czym powinna być sztuka). Oszukane - bo przeestetyzowane dzieło sztuki nie daje też spełnienia. Zastępuje prawdziwe przeżycia powierzchowną namiastką, tanią rozrywką ${ }^{42}$.

${ }^{39}$ Na przykład w parodiującej kiczowatość arystokracji noweli Biesiada $u$ hrabiny Kotłubaj narrator występuje w niezwykle sztampowej roli „prostaczka w salonie"; pisarz sam tkwi w kiczowych postaciach, które parodiuje; zob. J. Jarzębski, op. cit., s. 58.

40 Ibidem, s. 60 .

${ }^{41}$ Na pewne tropy tu podjęte zwróciłam uwagę już wcześniej; zob. D. Jaszewska, Nasza niedojrzała kultura. Postmodernizm inspirowany Gombrowiczem, Warszawa 2002.

${ }^{42}$ H. Broch, op. cit., s. 115. 
Tymczasem estetyzacja to zjawisko, które jest kwintesencją współczesnej kultury. A skoro estetyzacja to drugie imię kiczu, znaczy to, że żyjemy dziś w czasach jego dyktatury. Zgadza się z tym nawet Wolfgang Welsch, filozof łączony z postmodernizmem, teoretyk estetyzacji i zarazem krytyk jej najbardziej wulgarnego, prymitywnego wymiaru - powszechnego upiększania wszystkiego, co się da, „pozłacania” i „nabłyszczania” klamek, koszy na śmieci, sklepów, ulic itd. Takie zjawisko filozof określa mianem estetyzacji powierzchownej i utożsamia z kiczem. Przeciwko niemu stosuje on apel o kulturę „ślepej plamki”; zwraca bowiem uwagę na zagrożenie anestetyzacją (odwrotnością estetyzacji), która powoduje nieczułość na bodźce, na piękno, wywołane przesyceniem się powszechną ładnością ${ }^{43}$.

Do tego momentu Welsch zachowuje swoje modernistyczne poglądy odrzuca kicz jako tanie oszustwo. Ale też, podobnie jak Gombrowicz, nie jest on całkiem odporny na moc upiększania, tkwiącą we współczesnej kulturze. Przechodzi na stronę postmodernizmu, gdy obwieszcza zwycięstwo estetyki nad etyką i estetyce właśnie wyznacza bardzo istotne miejsce we współczesnej hierarchii wartości (w sytuacji postmodernistycznego kryzysu Rozumu) ${ }^{44}$. Podobnie postępuje inny teoretyk współczesnej estetyzacji, Richard Shusterman, głosząc, iż wobec horror vacui, jakie pozostawiły po sobie upadłe Wielkie Narracje, nie możemy wzgardzić kryteriami estetycznymi ${ }^{45}$. Dlatego Welsch nazywa estetykę mianem współczesnej filozofii pierwszej. I dlatego poszukuje głębszej teorii estetyzacji, wiążąc ją z przenikającymi nasz świat mediami, z plastycznością wizualnej kultury, wreszcie $-\mathrm{z}$ kondycją nowego człowieka, homo aestheticus, kierującego się w życiu formą i kryteriami estetycznymi ${ }^{46}$. Estetyzacja polega tu na wszechobecnej stylizacji, będącej poniekąd parodią Nietzscheańskiego „stwórz się" (zauważmy: kiedyś kobiety po prostu się ubierały, dziś dobi e rają stylizacje). Nie bez sarkazmu Welsch pisze, że w sytuacji, gdy padają kanony moralne, można przynajmniej zaimponować komuś wiedzą, jak

${ }^{43}$ W. Welsch, Estetyka poza estetyką. O nową postać estetyki, tłum. K. Guczalska, Kraków 2005, s. 70-73.

${ }^{44}$ Ibidem, s. 60.

45 R. Shusterman, Estetyka pragmatyczna Żywe piękno i refleksja nad sztuka, tłum. A. Chmielewski, Wrocław 1998, s. 319.

${ }^{46}$ W. Welsch, Estetyka poza estetyka..., op. cit., s. 73. 
właściwie dobrać kieliszki do obiadu ${ }^{47}$. Potęga gustu - to coś, czym nie sposób wzgardzić w czasach, gdy „runęły metanarracje”. Jakże pasuje do tego Gombrowiczowskie stwierdzenie:

Bo nic, co jest smaczne, nie może być straszne (jak samo słowo „smaczne” na to wskazuje), tylko niesmaczne jest naprawdę niejadalne. [...] I dlaczegóż taka paniusia, która nieulękłym palcem rozdrapuje najkrwawsze bolączki społeczne, śmierć głodową robotniczej rodziny złożonej z sześciorga osób, dlaczegóż, pytam, tym samym palcem za nic nie odważy się w uchu publicznie podłubać. Dlatego, że to byłoby znacznie okropniejsze. Śmierć głodowa albo, na wojnie, śmierć miliona ludzi, da się zjeść, nawet ze smakiem - ale wciąż istnieją na świecie kombinacje niejadalne, womitalne, złe, dysharmonijne, odpychające i odstręczające, ach, szatańskie, które zrzuca organizm ludzki. A smakować jest przecie naszym najpierwszym zadaniem, smakować musimy, smakować, niech kona mąż, żona i dzieci, niech serce rozdziera się na strzępy, byle smacznie, byle smakowicie! ${ }^{48}$

Podobnie jak Welsch, Gombrowicz jest krytyczny wobec takiej formy estetyzacji etyki. Można też powiedzieć, że tak jak Welsch dostrzega miałkość i prymitywizm powierzchownej estetyzacji. W napisanych przez siebie Rozmowach z Gombrowiczem tak komentuje motyw Nowoczesnej Pensjonarki:

Na przykład: ideał piękności kobiecej w Ferdydurke, jej Wenus, to „nowoczesna pensjonarka" fascynująca łydkami [...]. W Ferdydurke pełno takich niedojrzałych ideałów, mitów gorszego gatunku, takiej piękności drugiej klasy, uroków tandetnych, wątpliwych czarów... ${ }^{49}$

A więc - niedojrzałość, tandeta, kicz! A przy tym jednak mała doskonałość, jak choinka i śnieżek wtopione w szklaną, idealnie okrągłą kulę, kojące serce i głowę współczesnego intelektualisty. I tu zaczyna się ambiwalencja obu filozofów. Welsch, chcąc nie chcąc, przyznaje, że wiedza na temat kieliszków jest dziś nie do podważenia i nie do pogardzenia. Podobnie kwituje

${ }^{47}$ Ibidem.

48 W. Gombrowicz, Ferdydurke, op. cit., s. 139.

49 W. Gombrowicz, Testament. Rozmowy z Dominique de Roux, tłum. I. Kania, Kraków 1996, s. 62. 
Gombrowicz (w osobie Józia z Ferdydurke) swój podziw i bezradność wobec siły zjawiska estetyzacji:

Lat szesnaście, sveater, spódnica, gumiane sportowe półbuciki, wysportowana, swobodna, gładka, gibka, giętka i bezczelna! Na jej widok struchlałem w duchu i na twarzy. Zrozumiałem na pierwszy rzut oka, że oto - zjawisko potężne, potężniejsze bodaj od Pimki i równie absolutne w swym rodzaju ${ }^{50}$.

Kreśląc tak sugestywny portret Nowoczesnej Pensjonarki, Gombrowicz przechodzi na stronę kultury wizualnej i przedstawia nam kicz, który właściwie jest obrazem, pięknym jakąś zniewalającą mocą. Kicz, który naprawdę jest uroczy, a co gorsza - stylowy, jest o wiele bardziej niebezpieczny, gdyż zdaje się naprawdę obiecywać upragnioną doskonałość.

Gombrowicz, tak wrażliwy na piękno „drugiej klasy”, wygląda więc na proroka współczesnej estetyzacji, obecnej w czasach bezwzględnego prymatu kultury masowej. Wydaje się bowiem, że granicę dwóch stref - Dojrzałości i Niedojrzałości - między którymi swobodnie przepływa kicz (według klarownego podziału dokonanego przez Jarzębskiego ${ }^{51}$ ), dodatkowo podmywa dziś bezbrzeżna fala kultury popularnej. Spójrzmy: łatwa i przyjemna, pociągająca „sztuka szczęścia” nie musi być dziś wcale naiwna, a więc stać po stronie Niedojrzałości i Młodości. W kulturze masowej Młodość staje się wykalkulowaną Dorosłością, a Niedojrzałość przybiera postać doskonałej Formy - małego, ale w pewnym sensie doskonałego dzieła sztuki, jak ready mades Duchampa, powielone wizerunki Marylin Monroe czy puszka coca-coli. To jest sztuka dzisiejszych czasów, w których zresztą słowo „galeria” powszechnie kojarzone jest nie z wystawą dzieł sztuki, ale z wystawą sklepową, z rajem hipermarketu. Pod znakiem zapytania stoi zresztą status produktów kultury masowej jako kiczu. Mowa tu o gadżetach, cackach technologicznych, emblematach kultury masowej, które - jak pisze Elżbieta Anna Sekuła - są wyrazem współczesnej postawy akceptacji kiczu i zdążyły przejść metamorfozę „od bylejactwa i powielenia masowego do

50 W. Gombrowicz, Ferdydurke, op. cit., s. 101.

51 Mowa o dychotomicznym podziale na strefy „formy i chaosu, Dojrzałości i Niedojrzałości, Wyższości i Niższości, Starości i Młodości”. J. Jarzębski, op. cit., s. $55-56$. 
profesjonalizacji oraz perfekcjonizmu detali"'52. Zauważmy, że zapowiadały je już „gadżety” w pokoju Zuty Młodziakówny, tworzące swoisty i znaczący zestaw: gumiane półbuciki + jabłko + fotografia Freda Astaire’a i Ginger Rogers + tapczan z chowaną pościelą + zimny prysznic + telefon. „Jakże skromnie, a jak mocno!" ${ }^{33}$ To jak zestaw Parky Patt z powieści Philipa Dicka, który miał odciążyć skołatane głowy zdobywców kosmosu: kolekcja estetycznych laleczek, którymi bawili się dorośli, zażywszy uprzednio specjalne narkotyki, tak jak dzieci bawią się lalkami Barbie ${ }^{54}$. Czy to jeszcze kicz, czy może współczesna sztuka ery powszechnej estetyzacji? Minimalizm, uproszczenie, estetyczność - to niezwykle pociąga umęczonego wielością mieszkańca czasów późnej nowoczesności. Gadżety są jak bożki, wykute $\mathrm{z}$ brązu przedmioty pożądania Żydów, dla których porzucamy Boga wielkiej sztuki... bo takie doskonałe, lśniące. Zdają się - znacznie bardziej przekonująco niż Niewidoczny - obiecywać cuda.

Jarzębski twierdził, że obłędne doszukiwanie się ukrytych znaczeń i szyfrów związanych z postacią Młodziakówny można odczytać jako drwinę Gombrowicza $\mathrm{z}$ awangardowej poezji ${ }^{55}$. Wydaje mi się, że jest $\mathrm{w}$ tym coś więcej - fascynacja formą, wirującymi w powietrzu znakami, które znaczą już tylko same siebie; życiem na powierzchni, ale pięknym i estetycznie dopracowanym. Tę Gombrowiczowską wrażliwość na formę i znaki trafnie opisały potem koncepcje filozoficzne ery ponowoczesnej - na przykład Jean Baudrillard i jego koncepcja simulacrum jako pustego znaku ${ }^{56}$.

Gombrowicz uległ zniewalającej estetyce kultury masowej - uległ więc kiczowi! Inaczej niż Witkacy, wiernie broniący swoich arystokratycznych gustów, uznający radio za szczyt barbarzyństwa, Gombrowicz pod koniec życia bez zażenowania przyznawał, że jest wielbicielem kina i telewizji, że lubi

52 E.A. Sekuła, B. Kangur, op. cit., s. 42.

53 W. Gombrowicz, Ferdydurke, op. cit., s. 146.

${ }^{5}$ Ph.K. Dick, Trzy stygmaty Palmera Eldritcha, tłum. A.Z. Królicki, Poznań 2012.

55 J. Jarzębski, op. cit., s. 59.

56 J. Baudrillard, Precesja symulakrów, tłum. T. Komendant, [w:] Postmodernizm. Antologia przekładów, red. R. Nycz, Kraków 1998. 
„prawie wszystkie filmy" 57 (pamiętam moje zdziwienie, gdy usłyszałam, że Czesław Miłosz w podeszłym wieku uwielbiał oglądać serial „Złotopolscy”). Jak się wydaje, autora Ferdydurke pociągała ich przewidywalność, stylowość, scalenie, skończoność, kunszt; „mała doskonałość” gatunków filmowych. Gombrowicz uległ więc kiczowi, ale temu lepszej jakości, oznaczającemu nie stereotyp, ale „ikonę kultury masowej”, nie tandetę (złe wykonanie), ale perfekcyjność. Uległ kiczowi okupionemu ciężką pracą: producentów filmu, ale też... Zuty z trzęsącymi się lokami, poddającej ciało zimnemu prysznicowi. Kiczowi gotowemu, prostemu, a jednak wymagającemu trudu, hartu (jak u dzisiejszych celebrytek fitness). Uproszczonemu i niezbyt wyrafinowanemu intelektualnie, a jednak pełnemu zadziwiającej mądrości, ascezy, dyscypliny (zauważmy: wyświechtane mądrości Internetu, zdania w rodzaju: „lepiej mniej niż więcej”, nabierają jednak wartości, gdy poparte są autentycznym fizycznym wysiłkiem gwiazdy odchudzania się - świętej dzisiejszych czasów).

Można zatem pokusić się o typologię kiczu pod względem jego estetycznej mocy: od kiczu łagodnego, którego można zazdrościć jedynie trochę, a który pozwala intelektualiście na dystans (jak „fajnie” wierzą katolicy z odpustu; jak miło tańczą goście na weselu; jaka słodka ta dziewczyna, Zosia, i jaki dobry z niej materiał na żonę), po potężne zjawiska typu „Zuta the Modern” (ale już nie jej rodzice, którzy są śmieszni jak inne figury Gombrowicza). Kicz może być zwykłą szmirą, złą sztuką, z której intelektualista może się pośmiać (wulgarnie „zrobiona” dziewczyna, disco polo, odpustowe „potworki”), ale może też być perfekcyjnie wykonany, pociągający, doskonały. Tak jak amerykańska kultura, jej westerny i musicale, jej guma do żucia itd. ${ }^{58}$ Gombrowicz mógł wyśmiewać ów „słaby kicz”, zarazem jednak pokazywał, że coraz bardziej jesteśmy bezradni wobec zniewalającego, perfekcyjnego piękna produktów kultury masowej.

57 Zob. P. Sanavio, Gombrowicz: forma i rytuat (wywiad z listopada 1968 roku), [w:] Gombrowicz filozof, op. cit., s. 36.

58 Zob. J. Baudrillard, Ameryka, tłum. R. Lis, Warszawa 2001. 


\section{Bibliografia}

Theodor W. Adorno, Teoria estetyczna, tłum. K. Krzemień-Ojak, PWN, Warszawa 1994.

Hermann Broch, Kilka uwag o kiczu i inne eseje, tłum. J. Garewicz, D. Borkowska, R. Turczyn, „Czytelnik”, Warszawa 1998.

Jean Baudrillard, Precesja symulakrów, tłum. T. Komendant, [w:] Postmodernizm.

Antologia przekładów, red. R. Nycz, Wydawnictwo Baran i Suszczyński, Kraków 1998.

Grzegorz Dziamski, Co oznacza formuła „kryzys estetyki”?, „Kultura Współczesna” 1995, nr 3/4.

Philip K. Dick, Trzy stygmaty Palmera Eldritcha, tłum. A.Z. Królicki, REBIS, Poznań 2012.

Ernest Gellner, Postmodernizm, rozum i religia, tłum. M. Kowalczuk, PIW, Warszawa 1997.

Witold Gombrowicz, Dziennik 1966-1969, Wydawnictwo Literackie, Kraków 1992. Witold Gombrowicz, Ferdydurke, Wydawnictwo Literackie, Kraków 1987.

Witold Gombrowicz, Testament. Rozmowy z Dominique de Roux, tłum. I. Kania, Wydawnictwo Literackie, Kraków 1996.

Gombrowicz filozof, red. F.M. Cataluccio, J. Illg, tłum. K. Bielas, F.M. Cataluccio, Znak, Kraków 1991.

Jerzy Jarzębski, Kicz jest w nas: Gombrowicza romans z kiczem, „Teksty Drugie” 1996, nr 4(40).

Dagmara Jaszewska, Nasza niedojrzała kultura. Postmodernizm inspirowany

Gombrowiczem, Oficyna Naukowa, Warszawa 2002.

Marek Kwiek, Richarda Rorty'ego postmodernistyczny świat ironii, „Kultura Współczesna" 1993, nr 1.

Jakub Lubelski, Gombrowicz, zrozpaczony konserwatysta, „Pressje” 2013, nr 34. Jakub Lubelski, Ssanie. Głód sacrum w literaturze polskiej, Fundacja Świętego Mikołaja, Warszawa 2015.

José Ortega y Gasset, Bunt mas, tłum. P. Niklewicz, „Muza”, Warszawa 2006.

Dwight McDonald, Teoria kultury masowej, [w:] Kultura masowa, wybór, tłum. i oprac. Cz. Miłosz, Wydawnictwo Literackie, Kraków 2002.

Abraham Moles, Kicz, czyli sztuka szczęścia. Studium o psychologii kiczu, tłum. A. Szczepańska, E. Wende, PIW, Warszawa 1978.

Krzysztof Piątkowski, Kicz jako problem antropologiczny, [w:] Kiczosfery wspótczesności, red. W.J. Burszta, E.A. Sekuła, „Academica”, Warszawa 2008. 
Paweł Rojek, Gombrowicz i Wyszyński, „Pressje” 2013, nr 34.

Richard Rorty, Przygodność, ironia i solidarność, tłum. W.J. Popowski, Spacja, Warszawa 1996.

Elżbieta Anna Sekuła, Bezimienny Kangur, Kicz jako źródełko radości, [w:] Kiczosfery współczesności, red. W.J. Burszta, E.A. Sekuła, „Academica”, Warszawa 2008.

Richard Shusterman, Estetyka pragmatyczna. Żywe piękno i refleksja nad sztuka, tłum. A. Chmielewski, Wydawnictwo Uniwersytetu Wrocławskiego, Wrocław 1998.

Andrzej Szahaj, Ironia i miłość. Neopragmatyzm Richarda Rorty'ego w kontekście sporu o postmodernizm, Wydawnictwo Leopolnidum, Wrocław 2002.

Wolfgang Welsch, Estetyka poza estetyką. O nowa postać estetyki, tłum. K. Guczalska, Universitas, Kraków 2005.

Wolfgang Welsch, Stając się soba, tłum. J. Wietecki, [w:] Problemy ponowoczesnej pluralizacji kultury: wokół koncepcji Wolfganga Welscha, red. A. Zeidler-Janiszewska, Wydawnictwo Fundacji Humaniora, Poznań 1998.

Stanisław Ignacy Witkiewicz, Narkotyki. Niemyte dusze, PIW, Warszawa 1993.

\section{On Gombrowicz's Kitsch From the Perspective of the Theory of (Post)modernity}

The article develops the researches started by Jerzy Jarzębski; it discusses the phenomenon of kitsch in the work of Witold Gombrowicz. The study is based on a content analysis of selected fragments of works by this author (especially the novel under the title "Ferdydurke") and it refers to the selected concepts of modernity and postmodernity (W. Welsch, R. Rorty, J. Baudrillard). The writer himself is treated as an original philosopher of modernity (and later - postmodernity - thanks to this, he was ahead of his time). The work presents the thesis that we can assign to Gombrowicz - both the modernist sense of the category of kitsch and practices of its parody, as well as a peculiar tendency to kitsch and a tendency to play with kitsch. This tendency is analyzed in the article as an attitude corresponding with a postmodern condition, especially with its characteristic phenomenon called the aesthetization of culture, which was mentioned, among other things, by Wolfgang Welsch (culture of design, gadget and superficial styling). 
Philosophy of Gombrowicz in this sense corresponds with the postmodern rehabilitation of kitsch.

Keywords: kitsch, aesthetization of culture, gadget, pop culture, styling of life, postmodernity, modernity, Witold Gombrowicz 